\title{
Review \\ How to Build and to Protect the Neuromuscular Junction: The Role of the Glial Cell Line-Derived Neurotrophic Factor
}

\author{
Serena Stanga ${ }^{1,2,3, * \mathbb{D}}$, Marina Boido ${ }^{1,2,3} \mathbb{D}$ and Pascal Kienlen-Campard ${ }^{4} \mathbb{D}$ \\ 1 Department of Neuroscience Rita Levi Montalcini, University of Turin, 10126 Turin, Italy; \\ marina.boido@unito.it \\ 2 Laboratory of Brain Development and Disease, Neuroscience Institute Cavalieri Ottolenghi, University of \\ Turin, 10043 Orbassano, Italy \\ 3 National Institute of Neuroscience (INN), 10125 Turin, Italy \\ 4 Institute of Neuroscience (IoNS), Université Catholique de Louvain (UCLouvain), 1200 Bruxelles, Belgium; \\ pascal.kienlen-campard@uclouvain.be \\ * Correspondence: serena.stanga@unito.it
}

check for updates

Citation: Stanga, S.; Boido, M.;

Kienlen-Campard, P. How to Build and to Protect the Neuromuscular Junction: The Role of the Glial Cell Line-Derived Neurotrophic Factor. Int. J. Mol. Sci. 2021, 22, 136.

https://dx.doi.org/

10.3390/ijms22010136

Received: 30 October 2020

Accepted: 16 December 2020

Published: 24 December 2020

Publisher's Note: MDPI stays neutral with regard to jurisdictional claims in published maps and institutional affiliations.

Copyright: (C) 2020 by the authors. Licensee MDPI, Basel, Switzerland. This article is an open access article distributed under the terms and conditions of the Creative Commons Attribution (CC BY) license (https: / / creativecommons.org/ licenses/by/4.0/).

\begin{abstract}
The neuromuscular junction (NMJ) is at the crossroad between the nervous system (NS) and the muscle. Following neurotransmitter release from the motor neurons (MNs), muscle contraction occurs and movement is generated. Besides eliciting muscle contraction, the NMJ represents a site of chemical bidirectional interplay between nerve and muscle with the active participation of Schwann cells. Indeed, signals originating from the muscle play an important role in synapse formation, stabilization, maintenance and function, both in development and adulthood. We focus here on the contribution of the Glial cell line-Derived Neurotrophic Factor (GDNF) to these processes and to its potential role in the protection of the NMJ during neurodegeneration. Historically related to the maintenance and survival of dopaminergic neurons of the substantia nigra, GDNF also plays a fundamental role in the peripheral NS (PNS). At this level, it promotes muscle trophism and it participates to the functionality of synapses. Moreover, compared to the other neurotrophic factors, GDNF shows unique peculiarities, which make its contribution essential in neurodegenerative disorders. While describing the known structural and functional changes occurring at the NMJ during neurodegeneration, we highlight the role of GDNF in the NMJ-muscle cross-talk and we review its therapeutic potential in counteracting the degenerative process occurring in the PNS in progressive and severe diseases such as Alzheimer's disease (AD), Amyotrophic Lateral Sclerosis (ALS) and Spinal Muscular Atrophy (SMA). We also describe functional 3D neuromuscular co-culture systems that have been recently developed as a model for studying both NMJ formation in vitro and its involvement in neuromuscular disorders.
\end{abstract}

Keywords: neuromuscular junctions; neurotrophic factors; GDNF; neurodegenerative diseases; motor neuron diseases; AD; ALS; SMA; 3D neuromuscular model

\section{NMJ Structural Architecture and Peculiarities}

The development of the neuromuscular junctions (NMJs) is a complex chain of events in which many factors are intertwined in an extremely coordinated way. Briefly, the formation of NMJ requires first the guidance of the motor neuron (MN) axons toward the specific muscles for innervation and, secondly, the stabilization of the contact in order to form a mature NMJ. Indeed, this process of mature synapse formation is a key element for both the proper development and activity of the entire nervous system (NS). The neurotransmitter at the NMJ in skeletal muscle of vertebrates is Acetylcholine (Ach). Ach binds to nicotinic receptors (AchRs) on skeletal muscle fibers, thus inducing $\mathrm{Na}+$ entry at the post-synaptic membrane, $\mathrm{Ca}++$ release by the endoplasmic reticulum and finally fiber contraction. Non-myelinating terminal Schwann cells present at the NMJ contribute to its stabilization by capping the nerve terminal. Among macromolecules 
which participate in the synapse formation, the agrin-dependent pathway favors the clustering of AChRs. Indeed, initially dispersed along the muscle membrane, AChRs then slide towards the future NMJ and also local addition of AchRs are reported among the first events in NMJ formation. It involves the neuron-secreted proteoglycan agrin with its receptor, the lipoprotein receptor-related protein 4 (LRP4), the muscle-specific kinase (MuSK) and the regulatory soluble synapse-specific protease Neurotrypsin. Since MuSK is not able to directly bind Agrin, LRP4 mediates the process by forming a stable receptor/co-receptor assembly (for a complete review see [1]). The complex interplay between motor axons, terminal Schwann cells and the muscle fibers of the peripheral nervous system (PNS), is reminiscent of the tripartite synapse in the central nervous system (CNS) where pre- and post-synaptic neurons and astrocytes interact (Figure 1). Since defects in signal transmission between terminal nerve endings and muscle membranes are a common feature of several pathologic conditions, the neuro-muscular interplay represents a valuable model to study how the presynaptic message and the postsynaptic feedback collaborate to build a functional synapse, and how a pathological context can alter it.

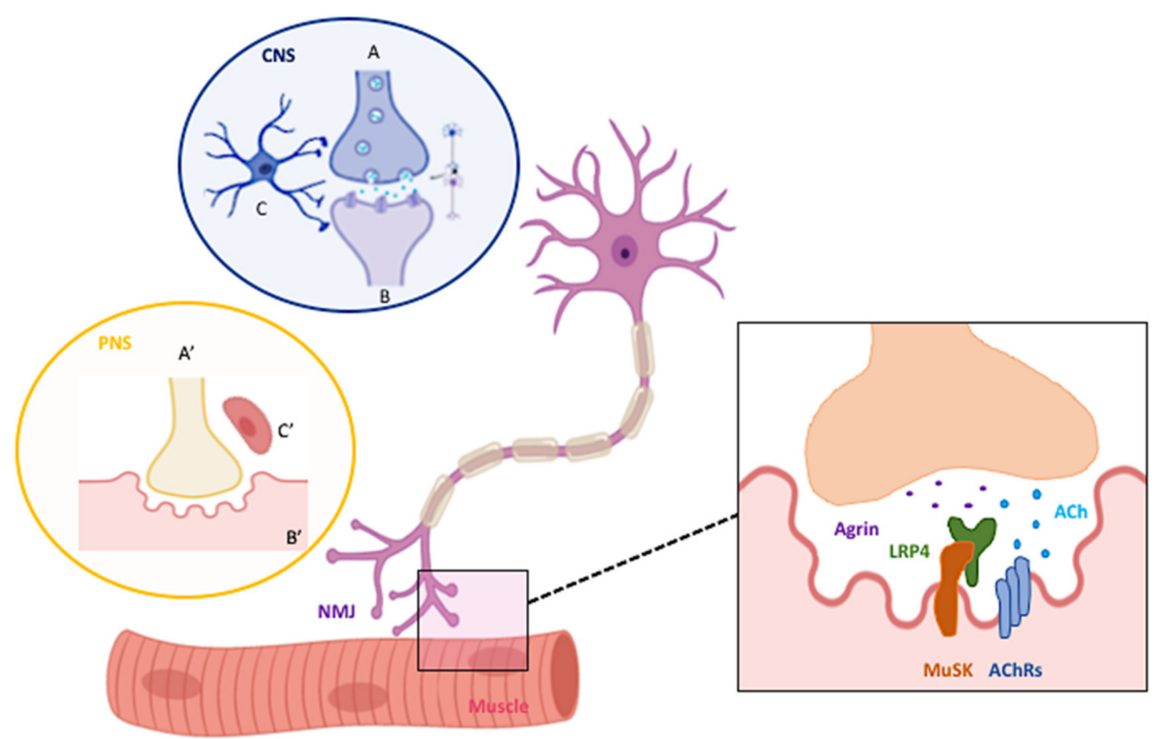

Figure 1. The central vs. the peripheral tripartite synapse. The NMJ is at the crossroad between the NS and the muscle, representing their cross-talk point. Central and peripheral synapses share a similar morphological feature: the tripartite synapse. Indeed, in the CNS the tripartite synapse is composed by a presynaptic axon (A), a postsynaptic dendrite (B) and by astrocytes (C). In the PNS, there is a comparable structure and the tripartite communication is between the axon terminal of the MN $\left(\mathbf{A}^{\prime}\right)$, the muscle fiber $\left(\mathbf{B}^{\prime}\right)$ and the terminal Schwann cells $\left(\mathbf{C}^{\prime}\right)$. The macromolecules involved at the nerve-muscle interplay are represented in the zoomed section. Created with BioRender software.

\section{Why Is It Relevant to Study the Neuro-Muscular Interplay in Neurological Disorders?}

Neurological disorders have been historically approached as "central diseases" because of their pathogenesis specifically linked to the CNS. However, it is becoming increasingly evident and generally accepted that they should be studied from a holistic perspective [2,3]. The nervous system (NS) and its effectors such as muscles, which meet at the NMJs, should be considered as a whole when investigating pathogenetic mechanisms. We must also underline the contribution of the PNS to the maintenance and survival of neuronal tissue of the CNS through mechanisms of retrograde signaling. Indeed, growth factors secreted from muscles are retrogradely transported to the MN cell body thanks to the NMJ-muscle interplay.

The correct formation and maintenance of the NMJ is fundamental for muscle function, i.e., also for vital and complex processes, such as breathing, feeding and locomotion. There- 
fore, muscle and NMJ degeneration also acquires a fundamental relevance in determining the quality of life and the autonomy of patients. Moreover, unproper NMJ formation with abnormal developmental synapse stabilization or improper NMJ maintenance during the progression of neuromuscular disorders, can trigger patient's death because of respiratory failure. Neurological disorders, related to the aging of the population, but also to underlying diseases, represent an important health issue. To better understand and prevent neurological disorders, the PNS, and particularly the NMJ, could represent an easy and accessible model to reveal what is occurring in the CNS. Strong experimental evidence throughout time and recently developed 3D neuromuscular models highlighted the great potential of NMJ as a reliable and non-invasive model to study mechanisms involved in synaptogenesis [4]. Indeed, different animal models have provided basic fundamental milestones for the understanding of the guidance of growth cones and motor axons toward their muscle targets (many examples come from studies in Drosophila, C. elegans or mouse).

\section{Overview of the Neurotrophic Factor Support in the NS}

Neurotrophic factors (NFs) are molecules secreted in order to support neuronal cells from their birth to differentiation into mature neurons [5]. Indeed, NFs promote cells' development, differentiation and survival and, in the mature NS, they are critical for more complex activities such as the formation of synaptic plasticity and long-term memory. They have been largely studied for their potential therapeutic role in counteracting neurodegeneration [6]. However, their clinical use is limited because of difficulties especially related to protein delivery and pharmacokinetics in the CNS [7]. Moreover, NFs support the maintenance of complex structures (such as the NMJ) and their functionality; indeed, they are mostly—but not only—released by neuronal cells. Being soluble and diffusible factors, NFs work as inter-cellular communicators, which can be easily secreted and uptaken by cells. Depending on the specific secreting cell types and on the structure of the NFs, they are organized in superfamilies and families, whose sub-members possess peculiar characteristics and functions, which are summarized in Table 1 and described below.

The nerve growth factor (NGF)-superfamily, originally called neurotrophins, includes the nerve growth factor (NGF), the brain-derived neurotrophic factor (BDNF), neurotrophin-3 and 4 (NT-3, NT-4). These NFs can promote neuron survival by interacting with the neurotrophic tyrosine receptor kinases (Trks/NTR), or apoptosis and cell death by interacting with p75NTR [8]. NGF is the first member of the family that has been identified for its capability to induce neurite outgrowth in explants from sympathetic and sensory ganglia [9]. During development, the NGF superfamily and their receptors are present in axons and dendrites of growing neurons, in the trigeminal ganglion, and in pre- and postsynaptic terminals of neurons through adulthood. The most studied in relation to neurodegenerative processes are NGF and BDNF. NGF is highly produced by neurons within the central cholinergic system; changes in its expression have indeed been associated with an aging-and-brain-damage-dependent decrease in cognitive function [10]. BDNF is more specifically expressed in the hippocampus, cerebral cortex and amygdaloid complex [11]. Changes in its levels and activity in the CNS have been described in different neurodegenerative disorders [12]. Besides the CNS, peripheral tissues produce low concentrations of neurotrophins to maintain appropriate levels of neuronal survival and innervation. Indeed, unlike the CNS, once the junction is formed, it does not require neurotrophins signaling for the modulation of the neuromuscular transmission [13]. 
Table 1. NF superfamilies, families and sub-members' major functions and expression at the peripheral level. Human NFs are listed in the table. Symbols + or ++ are used to indicate the degree of expression and level of secretion in peripheral tissues under physiological conditions: + low levels; + + high levels. The expression levels in peripheral tissues of the NFs in bold (GDNF, CNTF and IGF1) are the most representative of the family.

\begin{tabular}{|c|c|c|c|c|}
\hline Superfamilies & NFs Families & Submembers & $\begin{array}{l}\text { Families' Major } \\
\text { Functions }\end{array}$ & $\begin{array}{l}\text { Expression in } \\
\text { Peripheral } \\
\text { Tissues }\end{array}$ \\
\hline NGF & $\begin{array}{l}\text { NGF } \\
\text { BDNF } \\
\text { NTF3 } \\
\text { NTF4 }\end{array}$ & & $\begin{array}{l}\text { NS development, } \\
\text { Neuron survival } \\
\text { or apoptosis and } \\
\text { cell death, } \\
\text { Neurite } \\
\text { outgrowth }\end{array}$ & $\begin{array}{c}\text { Skeletal muscle } \\
+\end{array}$ \\
\hline \multirow{4}{*}{ TGF- $\beta$} & & $\begin{array}{c}\text { GDNF } \\
\text { Neurturin }\end{array}$ & & \\
\hline & GDNF family & $\begin{array}{l}\text { Artemin } \\
\text { Persephin }\end{array}$ & $\begin{array}{c}\text { NS } \\
\text { development, } \\
\text { NMJ formation } \\
\text { and } \\
\text { maintenance }\end{array}$ & $\begin{array}{c}\text { Skeletal muscle } \\
++ \\
\text { Schwann cells } \\
++\end{array}$ \\
\hline & TGF $\beta$ family & & & \\
\hline & BMP family & $\begin{array}{c}\text { TGF } \beta 1-3 \\
\text { BMP } 1-6,71,8 \mathrm{a}, \\
8 \mathrm{~b}, 10,15\end{array}$ & $\begin{array}{l}\text { NS development } \\
\text { Bone formation }\end{array}$ & $\begin{array}{c}\text { Immune system } \\
++ \\
\text { Schwann cells }+ \\
\text { Bone }++\end{array}$ \\
\hline $\begin{array}{l}\text { Neurokine or } \\
\text { Neuropoietin }\end{array}$ & $\begin{array}{c}\text { CNTF } \\
\text { LIF } \\
\text { IL-6 } \\
\text { IL-11 } \\
\text { CTF1 } \\
\text { Oncostatin-M } \\
\text { Granulocyte } \\
\text { colony- } \\
\text { stimulating } \\
\text { factor } \\
\text { Cardiotrophin-1 }\end{array}$ & & $\begin{array}{l}\text { NS development, } \\
\text { Regulation of } \\
\text { neurotransmit- } \\
\text { ter phenotype, } \\
\text { Neurons' rescue } \\
\text { from axotomy- } \\
\text { induced cell } \\
\text { death }\end{array}$ & $\begin{array}{c}\text { Skeletal muscle } \\
+\end{array}$ \\
\hline $\begin{array}{l}\text { Non-Neuronal } \\
\text { Growth Factors }\end{array}$ & $\begin{array}{c}\text { FGF1 } \\
\text { FGF2 } \\
\text { EGF } \\
\text { IGF1 }\end{array}$ & & NS survival & $\begin{array}{c}\text { Liver }++ \\
\text { Bone }+ \\
\text { Cartilage }+ \\
\text { Skeletal muscle } \\
+\end{array}$ \\
\hline
\end{tabular}

The transforming growth factor (TGF)- $\beta$ superfamily is divided into three families: the glial-cell-line-derived neurotrophic factor (GDNF) family, the TGF $\beta$ family, and the bone morphogenetic protein (BMP) family. The first two families play key functions during NS development, and also the TGF $\beta$ family in T cell differentiation during the immune response [14], while BMPs are mostly studied because of their role in bone formation and little is known about their actions in the NS. TGF $\beta 1$ is expressed principally by glial cells in the CNS and recruited after brain damage, while TGF $\beta 2$ and 3 are found in many neuronal populations and in both astrocytes and Schwann cells in low concentrations [15]. The GDNF family includes GDNF and three structurally related members called neurturin, persephin and artemin. GDNF is a potent NF importantly involved in the formation and maturation of the neuromuscular synapse during development and disease. It is abundantly produced in skeletal muscles and Schwann cells, and, compared to the other 
NFs, its effects at the level of the NMJ are mediated through multiple pre- and postsynaptic mechanisms resulting in quite profound effects that are described in details in the next paragraph.

The neurokine or neuropoietin superfamily includes the ciliary neurotrophic factor (CNTF), the leukemia inhibitory factor (LIF), interleukin (IL)-6 and 11, cardio- trophin1 (CTF1), the oncostatin-M, and the granulocyte colony-stimulating factor. All family members are related to the corresponding cytokines with whom they share similar tertiary structures. The neurokine family signals via the leukemia-inhibitory factor receptor (LIFR) and gp130 and is involved in the regulation of the neurotransmitter phenotype, neuronal and glial differentiation and development, and the rescue of neurons from axotomyinduced cell death [16]. CNTF is synthesized by muscles but it is not involved in NMJ maintenance; it prevents atrophy only in pathological states, such as in in response to nerve lesion [17].

Non-neuronal growth factors mainly include the fibroblast growth factors (FGF1 and 2), the epidermal growth factor (EGF) and the insulin-like growth factors (IGFs) FGF1 and 2, EGF and IGF1. They are present in large concentrations in the NS, where the most studied one is IGF-1. Together with its receptors, IGF-1 is expressed both in neurons and glial cells in the substantia nigra [18]. It is predominantly formed in the liver after stimulation by circulating growth hormone $(\mathrm{GH})$ and released by the pituitary gland; it is also synthesized in peripheral tissues (such as bone, cartilage and skeletal muscle) but in low concentrations.

In this scenario, we focus on GDNF since it is the most closely related to NMJ because of its high expression in muscles and Schwann cells from development to adulthood; furthermore, since its contribution also in pathological conditions, it has been largely studied and tested in clinical trials for many neurodegenerative disorders [19].

\section{The Role of GDNF at the NMJ}

GDNF together with neurturin, artemin and peserphin is a sub-member of the GDNF family which is structurally related to the TGF-superfamily. Neurturin, artemin and peserphin are, respectively, involved in the support and survival of nigrostriatal neurons [20], sensory and sympathetic peripheral neurons [21] and of motor and midbrain dopaminergic neurons [21]. GDNF has been originally isolated from the conditioned media of a rat glioma cell line. Its first property as a trophic factor has been observed on primary cultures of dopaminergic neurons. It has been therefore largely studied for Parkinson's Disease (PD) and evaluated in clinical trials [22,23]. As with all the other family members, GDNF acts by interacting with specific receptors to trigger different signaling cascades. Canonically, it forms a complex with GDNF family receptor alpha-1 (GFR $\alpha 1$ ), its primary receptor, which could be either membrane bound or soluble [24,25]. The so-formed complex activates the co-receptor tyrosine kinase REarranged during Transfection (RET) present on neuronal cell bodies and terminals and activates downstream pathways related to MAP kinases and Akt [26]. With a lower affinity, the GDNF-GFR $\alpha 1$ complex can signal via the RETindependent mechanism with the neural cell adhesion molecule (NCAM); GDNF can also signal independently from GFR $\alpha 1$ by interacting with the heparin sulfate proteoglycan syndecan-3 $[27,28]$. Originally thought to be secreted by glial cells, GDNF is also produced by neuronal cells in basal condition, while activated astrocytes are producing and releasing it in case of need, i.e., injury, inflammation and neurodegeneration [29,30]. Indeed, GDNF (which is mostly expressed during development) [31-34] is present in a healthy adult brain in the healthy adult striatal medium spiny neurons [35] and in the hippocampus [36], and it acts mainly on RET-expressing neurons. In MNs, in addition to the support of proliferation and maturation, GDNF participates in the regeneration of damaged axons and modulates the NMJ $[37,38]$.

Moreover, GDNF is also expressed in cells located outside the CNS such as in peripheral nerve axons, Schwann cells [39] and skeletal muscles [40-42]. From there, it can be retrogradely transported to the soma of MNs as demonstrated by an in vitro model of the compartmentalized microfluidic neuromuscular co-culture system [43]. It also participates 
in NMJ formation and maintenance and its ability to induce neurite sprouting in axonal injury models has been clearly demonstrated [44,45]. Indeed, after spinal cord injury (SCI), GDNF is upregulated specifically in Schwann cells for weeks, making them important as potential points of intervention for SCI therapies [46,47]. Therefore, new attention and interest, relative to the neuronal population and to the mechanisms involved in GDNF secretion, is rising (for a recent review see [48]).

GDNF can modulate the NMJ formation and functioning both at pre- and postsynaptic levels. Indeed, once secreted by muscles, GDNF is retrogradely transported to RET-expressing MNs [49], where it regulates presynaptic maturation. GDNF is one of the most potent survival factors for MNs [37,50]. In vitro experiments demonstrated its ability to increase the amplitude and the frequency of spontaneous synaptic currents [51], while in mice overexpressing GDNF or after GDNF administration the NMJs are hyperinnervated [52]. Moreover, in muscles/MNs co-cultures, GDNF and Neurturin are able to (i) enhance the aggregation of ACh synaptic vesicles at the presynaptic terminal areas facing the NMJ, (ii) enhance neurotransmitter release and iii) induce AChR clustering at the postsynaptic terminal [53]. A more recent study demonstrated with an elegant microfluidic chamber model that GDNF promotes axon growth, only when it is applied to the NMJ, and not to the soma [43]. Indeed, GDNF can influence the maturation of the postsynaptic site and can also induce myocyte differentiation. In muscle cell lines, GDNF expression favors myoblasts differentiation into myotubes and spontaneous contraction in vitro [54]. In basal conditions, GDNF participates to the maintenance of the junction and to its continuous remodeling by stimulating the endplate size and complexity $[53,55,56]$. GDNF is also an activity-dependent factor and its secretion is elicited in case of damage, in order to promote pro-survival mechanisms, or as a positive outcome of physical exercise involving muscles. Indeed, GDNF expression relies on the recruitment of the myofibers during physical activity $[57,58]$. Moreover, when GDNF is overexpressed in muscle, an increase in the number of fast-twitch and fatigue-resistant (type IIa) fibers is observed, and this phenomenon correlates with functional tests [34]. On the contrary, it has been observed that muscles that are not actively recruited during exercise display no changes in NMJ morphology, and GDNF levels remained similar to those in sedentary controls [59].

To summarize, GDNF has been shown to be (i) the most abundant factor released by both skeletal muscles and Schwann cells; (ii) to be secreted at the NMJ during development and also adulthood; (iii) to be a fundamental NF for the formation of NMJ both at the pre-synaptic site-for ACh vesicles aggregation-and at the post-synaptic site-for AChR clustering; (iv) to be a neuromodulator able to exert long-term regulatory effects on synaptic transmission; (v) to exert a protective role during peripheral degeneration occurring in neurodegenerative disorders.

\section{The NMJ-GDNF Cross-Talk: What Goes Wrong During Neurodegeneration?}

In different progressive and severe neurodegenerative processes, besides the CNS, there is also a clear involvement of peripheral tissues, especially of mitochondria-enriched muscles and NMJs. Their structural impairment and loss of function, often occurring before symptom onset, increase progressively during degeneration. These early phenomena are largely described both in animal models and in patients (for a recent review see [60]). Because of the significant involvement of the GDNF at the NMJ, we highlight here the GDNF/NMJ cross-talk in the context of severe disorders such as Alzheimer's disease (AD), Amyotrophic Lateral Sclerosis (ALS) and Spinal Muscular Atrophy (SMA).

$\mathrm{AD}$, the most common form and cause of dementia, is a major social health problem and, the in absence of a meaningful treatment, it remains a major scientific and medical challenge. The neurodegenerative process has always been studied with a 'central' approach following its pathological hallmarks-amyloid plaques and tau neurofibrillary tangles-which accumulate in vulnerable CNS regions. Related to amyloid deposits, it has been recently observed that GDNF is able to decrease proinflammatory mediators exerting an anti-inflammatory function in AD. Indeed, GDNF treatment is able to control 
amyloid-beta $(\mathrm{A} \beta)$-induced inflammatory response in microglia [61]. Moreover, the role of GDNF in astrocytes, oligodendrocytes and microglia in regulating tissue clearance from $\mathrm{A} \beta$ deposition in the brain is increasingly studied [62]. Interestingly, AD-related proteins such as the Amyloid Precursor Protein (APP) family members-APP and the two paralogs Amyloid Precursor-like Protein1 and 2 (APLP1 and APLP2) - have been associated to NMJ formation. Indeed, APP family members work as transsynaptic regulators: MN APP interacts with Lrp4 expressed at the level of the muscles, promoting MuSK activation and NMJ formation and stabilization [63,64]. Muscular APP controls the expression of the GDNF involved in the maintenance of the NMJ [54]. Presenilins (PSs) are the catalytic subunit of the gamma-secretase involved in A $\beta$ release upon APP processing [65-67]. More recently, a discrimination between PS1 and PS2 catalytic properties has been established [68], and their involvement in cellular bioenergetics and mitochondrial respiration [69] supports their potential role in muscle trophism and NMJ formation.

ALS and SMA are mainly categorized as MN disorders. Besides MN degeneration, they are largely characterized by muscle and NMJ degeneration. Although both are considered rare disorders, on one side it has been estimated that by 2040 around 400,000 patients will be diagnosed with ALS worldwide [70], and on the other SMA it is the leading cause of infant mortality due to genetic causes (i.e., mutation of the survival motor neuron-1—SMN1—gene) [71].

In ALS, GDNF is playing an important protective role at the level of the NMJ. Indeed, bilateral administration of GDNF into the tibialis anterior, the forelimb triceps brachii and into the long muscles of the dorsal trunk in a familiar rat model of ALS, preserves the NMJ, promotes MN function and survival [72], and muscle-specific GDNF overexpression increases the lifespan of an ALS mouse model [73]. On the contrary, systemic injection of AAV9-GDNF to young rats, in a model of ALS, did not increase lifespan; even though AAV9-GDNF injection resulted in modest functional improvement, important sides effects related to systemic injection (i.e., slower weight gain, reduced activity levels and decreased working memory) were observed [74]. Interestingly, in ALS, MN degeneration is probably preceded by NMJ denervation. Indeed, in muscles from both mouse models of familial ALS and in ALS patients, APP is upregulated and its expression correlates with the progression of clinical symptoms [75,76]. Moreover, GDNF and soluble APP fragment levels are altered at the onset of motor deficits in the SOD1 transgenic mutant mouse model and in the cerebrospinal fluid (CSF) of patients [77]. Overall, this piece of evidence suggests a link between the ongoing denervation process and the attempt to counteract it by both GDNF and NMJ-related interactors, such as APP.

Concerning SMA, despite its well-known genetic origin, until 2017 no treatment was available. Nusinersen (Spinraza; Biogen), an antisense oligonucleotide, is the first drug approved by the Food and Drug Administration (FDA) (in December 2016) and by the European Medicines Agency (EMA) (in June 2017) for both infants and adults with SMA. Recently, two other drugs have been approved: Zolgensma (AVXS-101), an adenovirus by Avexis/Novartis (May 2019-FDA; May 2020-EMA), and Evrysdi (Risdiplam), a new oral drug by Genentech, a member of the Roche Group (August 2020-FDA). These drugs aim at restoring SMN levels [78]; however, since also in SMA NMJ degeneration is an early event, addressing the NMJ could represent a potential and adjunctive therapeutic target (for a review, see [79]). Indeed, NMJ degeneration in SMA occurs in parallel to the degeneration of mitochondria in spinal MNs (Figure 2). These organelles have been described as altered and fragmented, with compromised functional activity also in humans [80], impacting in turn on muscle trophism. Many groups described immature, small and fragmented NMJs in the most used SMA animal model, the SMN $\Delta 7$ mouse, compared to controls [81-83]. These defects precede the onset of motor symptoms underlying the importance of NMJ degeneration in the pathology $[84,85]$. Furthermore, one of the hallmarks of SMA pathology is the accumulation of neurofilament (NF), the cytoskeletal components of neurons, at the NMJ, highlighting its central role in the pathology. Indeed, NF accumulation at the NMJ results in altered organelles and trophic factor dynamics, negatively impacting on 
disease progression $[82,86]$. Few reports describe the alteration of GDNF levels in different tissues/fluids in SMA models. GDNF levels have been described as reduced in SMAinduced pluripotent stem cell (iPSC)-derived astrocytes, but lentivirus expression of GDNF in the model is not able to recover astrocytic processes or calcium signaling response [87]. In the CSF of SMA patients, GDNF levels, but not NGF and BDNF levels, were importantly increased compared to controls and authors suggested that it could be the results of a GDNF attempt to counteract the loss and damage of neuronal cells [88]. Considering the impairment of the NMJ in SMA and the role of GDNF at that level, further studies about its role in tissues more relevant to the pathology (such as the spinal cord, muscles and the NM-interplay) should be undertaken. Models of nerve-muscle co-cultures, which we describe in the paragraph below, could indeed help in the finding of new potential pathways involving the NMJ in SMA.

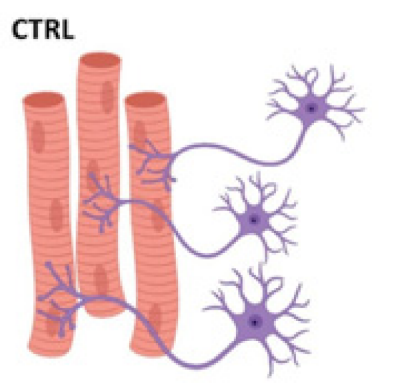

SMA

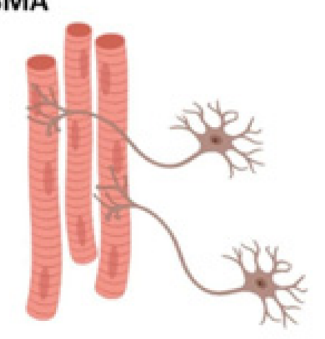

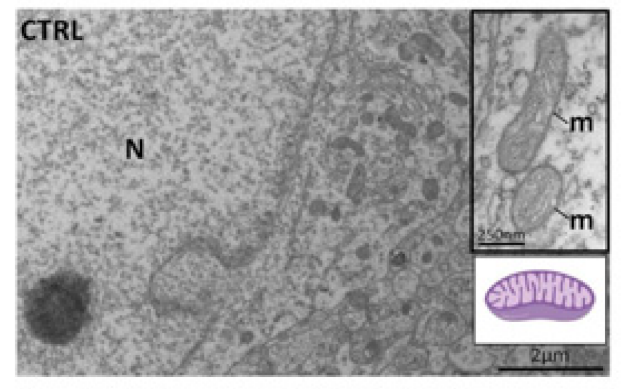

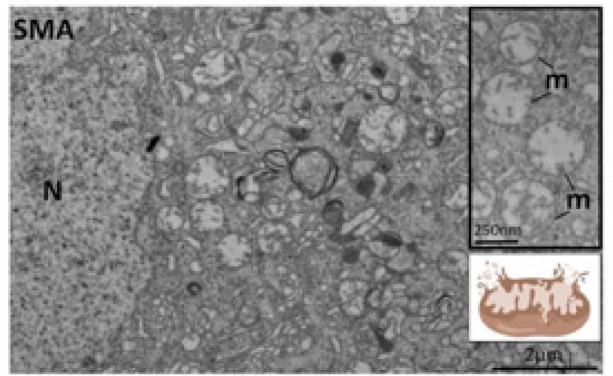

Figure 2. Peripheral dysfunctions in SMA. SMA is characterized by progressive MN death, impaired innervation and muscular atrophy, contributing to NMJ destabilization. Among the known pathogenic mechanisms, mitochondrial alterations represent an early event. As shown in the Electron Microscopy images from spinal cord samples of the SMN $\Delta 7$ mice (postnatal day 10), compared to the control (CTRL), SMA mitochondria are clearly altered, dilated and fragmented. $\mathrm{N}=$ nucleus; $\mathrm{m}=$ mitochondria. Created with BioRender software.

\section{3D Neuromuscular Models for NMJ Reconstruction}

Recently, experimental approaches based on 3D models to rebuild the neuromuscular contact in vitro have been developed and optimized. These models are useful not only to study the properties of maturing muscle fibers, but especially to unveil adult human NMJ formation and development. Indeed, NMJ maturation is a process requiring both muscle fibers and motor neurons; therefore, 3D approaches where muscle cells are co-cultured with MNs are needed for better investigating disease mechanisms and applying them to neurodegenerative models.

Different models can be set up by using (i) cell lines of muscle cells (C2C12 cells) and cholinergic or MN models (usually NG108-15, NSC-34), (ii) primary cells obtained from animal models (myoblasts and primary MNs or embryonic-derived spinal cord slices) or 3D co-cultures composed of (iii) human induced pluripotent stem cells (iPSCs) of myoblasts and MNs. Each model possesses its own characteristics and can be chosen and adapted in order to answer to the specific scientific question and/or applied to the peculiar disorder.

(i) 3D models performed with cell lines have the great advantage to be both handy and straightforward. Because of the dividing rate of the cells, NM contacts are rapidly 
obtained after $7 / 8$ days of culture. This model is particularly suitable for studies requiring silencing and/or overexpression of specific genes in order to mimic a pathological condition. Indeed, muscle and neuronal cell lines can be efficiently transfected in co-culture models [54]. However, it is important to note that manipulation of the cells via transfection could affect itself the formation of the NM contact and, furthermore, that the transfection process is only transient.

(ii) When NM contacts are performed with primary myoblasts and MNs or spinal cord slices, the timing for obtaining NM contacts is longer and can reach up to a month of culture [89]. Furthermore, a very precise coordination for animal crossings is needed in order to have pups at postnatal day P3-P5 for myoblasts cultures and, around 12-14 days after culture, embryos at E12,5 for MNs or spinal cord slices. On the other side, by working with cells/tissues derived from the animal model of interest, the disease is recapitulated without the need for further manipulation.

(iii) Recently, studies based on the co-culture of human iPSCs have been implemented. The major advantage of these techniques is to perform cultures with patient-derived cells (usually fibroblasts) that are specifically reprogrammed in order to generate iPSCs to be directly differentiated into muscle or MN cells (for a comprehensive review on the topic, see [90]). Two recent works have been published regarding 3D neuromuscular models based on iPSCs. The first model, by Bakooshli and colleagues consists in mixing human muscle progenitors with human pluripotent stem cell-derived MNs [91]. The co-cultures are able to self-organize to form functional NMJ connections. Authors validated the functional connectivity by calcium imaging and electrophysiological tests, and they applied the model to the study of myasthenia gravis. The second model, by Osaki and colleagues, is based on muscle and MN interaction through a microfluid device [92]. This model needs weeks to be implemented, but the advantage is that it permits to record in real time the NMJ formation and the synchronization of MN activity and muscle contraction.

It would be interesting to deepen the role of GDNF in 3D models for NMJ formation in health and disease. Such techniques represent the fundament for developing precision medicine and drug screening directed to the NMJ for neuromuscular disorders.

\section{Conclusions}

NMJ formation and maintenance require neurotrophic support. In this fine-tuned machinery, GDNF plays a pivotal role both in NMJ assembly and in maintaining the signaling between $\mathrm{MN}$ and muscles and vice versa. Indeed, GDNF supports a tightly coordinated assembly of pre- and postsynaptic structures and a strong reciprocal signaling between the two counterparts. The role of GDNF turns out to be decisive from development to aging passing through adulthood by promoting neuroplasticity and preventing from neurodegenerative disorders. Looking at neurodegenerative disorders as multisystemic disorders, the involvement of the periphery in the study of pathogenic mechanisms could represent a more successful approach also for finding new targets for therapies. Especially in the case of dementia, where a precise diagnosis is difficult in the early disease phase, researchers are largely studying peripheral biomarkers obtained from easily accessible peripheral fluids—such as blood-and by non-invasive methods [93-95]. Interestingly, since GDNF expression induced in response to exercise participates to the rejuvenation of the NMJ structure and function [59], it could be evaluated as a possible peripheral marker and possible targets. Furthermore, it could play a key role in delaying the onset of aging and neurodegenerative disorders by preventing NMJ degeneration. The study of the GDNF-NMJ cross-talk in recently developed 3D models and its monitoring could indeed be translated into accurate exercise and a healthy lifestyle prescription to elderly human subjects and patients with the aim to preserve the integrity of the neuromuscular system through aging and disease [96]. 
Author Contributions: Conceptualization, original draft preparation, manuscript writing and revision S.S.; critical editing M.B. and P.K.-C. All authors have read and agreed to the published version of the manuscript.

Funding: This work was supported by Ricerca Locale 2020 (University of Turin) granted to S.S., by Ministero dell'Istruzione dell'Università e della Ricerca MIUR project “Dipartimenti di Eccellenza 2018-2022" to the Department of Neuroscience "Rita Levi Montalcini" and by Girotondo/ONLUS and SMArathon-ONLUS foundations.

Acknowledgments: We are grateful to Julien Puyal (Département des Neurosciences Fondamentales \& Centre Universitaire romand de médecine légale, Unité Facultaire d'Anatomie et de Morphologie (UFAM), Universite de Lausanne, Switzerland) for the helpful technical assistance during the acquisition of EM images and for the accurate analysis of images. We are grateful to Alessandro Vercelli (University of Turin) for the critical reading of the review.

Conflicts of Interest: The authors declare that the research was conducted in the absence of any commercial or financial relationships that could be construed as a potential conflict of interest.

\begin{tabular}{|c|c|}
\hline Abbrev & \\
\hline NMJs & Neuromuscular Junctions \\
\hline $\mathrm{MN}$ & Motor Neuron \\
\hline Ach & Acetylcholine \\
\hline AChRs & Nicotinic Receptors \\
\hline LRP4 & Lipoprotein Receptor-Related Protein 4 \\
\hline Musk & Muscle-Specific Kinase \\
\hline PNS & Peripheral Nervous System \\
\hline CNS & Central Nervous System \\
\hline NFs & Neurotrophic Factors \\
\hline NGF & Nerve Growth Factor \\
\hline BDNF & Brain-Derived Neurotrophic Factor \\
\hline NT-3 & Neurotrophin-3 \\
\hline NT-4 & Neurotrophin-4 \\
\hline TGF- $\beta$ & Transforming Growth Factor- B \\
\hline $\mathrm{BMP}$ & Bone Morphogenetic Protein \\
\hline CNTF & Ciliary Neurotrophic Factor \\
\hline LIF & Leukemia Inhibitory Factor \\
\hline IL-6 & Interleukin-6 \\
\hline IL-11 & Interleukin-11 \\
\hline CTF1 & Cardio-Trophin-1 \\
\hline FGF1 & Fibroblast Growth Factor 1 \\
\hline FGF2 & Fibroblast Growth Factor 2 \\
\hline EGF & Epidermal Growth Factor \\
\hline IGF1 & Insulin-Like Growth Factor 1 \\
\hline GDNF & Glial-Cell-Line-Derived Neurotrophic Factor \\
\hline GFR $\alpha 1$ & GDNF family receptor alpha-1 \\
\hline RET & REarranged during Transfection \\
\hline NCAM & Neural Cell Adhesion Molecule \\
\hline $\mathrm{AD}$ & Alzheimer's Disease \\
\hline ALS & Amyotrophic Lateral Sclerosis \\
\hline SMA & Spinal Muscular Atrophy \\
\hline APP & Amyloid Precursor Protein \\
\hline APLP1 & Amyloid Precursor-Like Protein1 \\
\hline APLP2 & Amyloid Precursor-Like Protein2 \\
\hline PSs & Presenilins \\
\hline iPSCs & Human Induced Pluripotent Stem \\
\hline CSF & Cerebrospinal Fluid \\
\hline FDA & Food and Drug Administration \\
\hline
\end{tabular}




\section{References}

1. Guarino, S.R.; Canciani, A.; Forneris, F. Dissecting the Extracellular Complexity of Neuromuscular Junction Organizers. Front. Mol. Biosci. 2020, 6, 156. [CrossRef] [PubMed]

2. Bayati, A.; Berman, T. Localized vs. Systematic Neurodegeneration: A Paradigm Shift in Understanding Neurodegenerative Diseases. Front. Syst. Neurosci. 2017, 11, 62. [CrossRef] [PubMed]

3. Castillo, X.; Castro-Obregón, S.; Gutiérrez-Becker, B.; Gutiérrez-Ospina, G.; Karalis, N.; Khalil, A.A.; Lopez-Noguerola, J.S.; Rodríguez, L.L.; Martínez-Martínez, E.; Perez-Cruz, C.; et al. Re-thinking the Etiological Framework of Neurodegeneration. Front. Neurosci. 2019, 13, 728. [CrossRef] [PubMed]

4. Natarajan, A.; Sethumadhavan, A.; Krishnan, U.M. Toward Building the Neuromuscular Junction: In Vitro Models to Study Synaptogenesis and Neurodegeneration. ACS Omega 2019, 4, 12969-12977. [CrossRef] [PubMed]

5. Lanni, C.; Stanga, S.; Racchi, M.; Govoni, S. The expanding universe of neurotrophic factors: Therapeutic potential in aging and age-associated disorders. Curr. Pharm. Des. 2010, 16, 698-717. [CrossRef]

6. Bartus, R.T.; Johnson, E.M., Jr. Clinical tests of neurotrophic factors for human neurodegenerative diseases, part 1: Where have we been and what have we learned? Neurobiol. Dis. 2017, 97, 156-168. [CrossRef]

7. Levy, Y.S.; Gilgun-Sherki, Y.; Melamed, E.; Offen, D. Therapeutic Potential of Neurotrophic Factors in Neurodegenerative Diseases. BioDrugs 2005, 19, 97-127. [CrossRef]

8. Keller, G.B.; Barde, Y.-A. Signalling through the neurotrophin receptor p75NTR. Curr. Opin. Neurobiol. 1997, 7, 413-418. [CrossRef]

9. Hamburger, V.; Levi-Montalcini, R. Proliferation, differentiation and degeneration in the spinal ganglia of the chick embryo under normal and experimental conditions. J. Exp. Zool. 1949, 111, 457-501. [CrossRef]

10. Hellweg, R.; Von Richthofen, S.; Anders, D.; Baethge, C.; Röpke, S.; Hartung, H.-D.; Gericke, C.A. The time course of nerve growth factor content in different neuropsychiatric diseases-A unifying hypothesis. J. Neural Transm. 1998, 105, 871-903. [CrossRef]

11. Hofer, M.; Pagliusi, S.R.; Hohn, A.; Leibrock, J.; Barde, Y.A. Regional distribution of brain-derived neurotrophic factor mRNA in the adult mouse brain. EMBO J. 1990, 9, 2459-2464. [CrossRef] [PubMed]

12. Zuccato, C.; Cattaneo, E. Brain-derived neurotrophic factor in neurodegenerative diseases. Nat. Rev. Neurol. 2009, 5, 311-322. [CrossRef] [PubMed]

13. Mousavi, K.; Jasmin, B.J. BDNF Is Expressed in Skeletal Muscle Satellite Cells and Inhibits Myogenic Differentiation. J. Neurosci. 2006, 26, 5739-5749. [CrossRef]

14. Li, M.O.; Flavell, R.A. TGF- $\beta$ : A Master of All T Cell Trades. Cell 2008, 134, 392-404. [CrossRef] [PubMed]

15. Landreth, G.E. Growth factors. In Basic Neurochemistry, Molecular, Cellular and Medical Aspects, 6th ed.; Siegel, G.J., Agranoff, B.W., Albers, R.W., Fisher, S.K., Uhler, M.D., Eds.; Lippincott-Raven: Philadelphia, PA, USA, 1999; pp. 384-396.

16. Horton, A.R.; Bartlett, P.F.; Pennica, D.; Davies, A.M. Cytokines promote the survival of mouse cranial sensory neurones at different developmental stages. Eur. J. Neurosci. 1998, 10, 673-679. [CrossRef]

17. Curtis, R.; Adryan, K.M.; Zhu, Y.; Harkness, P.J.; Lindsay, R.M.; Distefano, P.S. Retrograde axonal transport of ciliary neurotrophic factor is increased by peripheral nerve injury. Nat. Cell Biol. 1993, 365, 253-255. [CrossRef]

18. Quesada, A.; Romeo, H.E.; Micevych, P.E. Distribution and localization patterns of estrogen receptor- $\beta$ and insulin-like growth factor- 1 receptors in neurons and glial cells of the female rat substantia nigra: Localization of ER $\beta$ and IGF-1R in substantia nigra. J. Comp. Neurol. 2007, 503, 198-208. [CrossRef]

19. Runeberg-Roos, P.; Penn, R.D. Improving therapeutic potential of GDNF family ligands. Cell Tissue Res. 2020, 382, 173-183. [CrossRef]

20. Rosenblad, C.; Kirik, D.; Devaux, B.; Moffat, B.; Phillips, H.S.; Björklund, A. Protection and regeneration of nigral dopaminergic neurons by neurturin or GDNF in a partial lesion model of Parkinson's disease after administration into the striatum or the lateral ventricle. Eur. J. Neurosci. 1999, 11, 1554-1566. [CrossRef]

21. Baloh, R.H.; Tansey, M.G.; Lampe, P.A.; Fahrner, T.J.; Enomoto, H.; Simburger, K.S.; Leitner, M.L.; Araki, T.; Johnson, E.M.; Milbrandt, J. Artemin, a Novel Member of the GDNF Ligand Family, Supports Peripheral and Central Neurons and Signals through the GFR $\alpha 3-$ RET Receptor Complex. Neuron 1998, 21, 1291-1302. [CrossRef]

22. Lin, L.F.; Doherty, D.H.; Lile, J.D.; Bektesh, S.; Collins, F. GDNF: A glial cell line-derived neurotrophic factor for midbrain dopaminergic neurons. Science 1993, 260, 1130-1132. [CrossRef] [PubMed]

23. Marks, W.J.; Bartus, R.T.; Siffert, J.; Davis, C.S.; Lozano, A.; Boulis, N.; Vitek, J.; Stacy, M.; Turner, D.; Verhagen, L.; et al. Gene delivery of AAV2-neurturin for Parkinson's disease: A double-blind, randomised, controlled trial. Lancet Neurol. 2010, 9 , 1164-1172. [CrossRef]

24. Paratcha, G.; Ledda, F.; Baars, L.; Coulpier, M.; Besset, V.; Anders, J.; Scott, R.P.; Ibáñez, C.F. Released GFR $\alpha 1$ Potentiates Downstream Signaling, Neuronal Survival, and Differentiation via a Novel Mechanism of Recruitment of c-Ret to Lipid Rafts. Neuron 2001, 29, 171-184. [CrossRef]

25. Baudet, C.; Ernfors, P. Soluble and bound forms of GFR?1 elicit different GDNF-independent neurite growth responses in primary sensory neurons. Dev. Dyn. 2003, 227, 27-34. [CrossRef]

26. Wang, X. Structural studies of GDNF family ligands with their receptors-Insights into ligand recognition and activation of receptor tyrosine kinase RET. Biochim. Biophys. Acta (BBA) 2013, 1834, 2205-2212. [CrossRef] [PubMed]

27. Paratcha, G.; Ledda, F.; Ibáñez, C.F. The Neural Cell Adhesion Molecule NCAM Is an Alternative Signaling Receptor for GDNF Family Ligands. Cell 2003, 113, 867-879. [CrossRef] 
28. Bespalov, M.M.; Sidorova, Y.A.; Tumova, S.; Ahonen-Bishopp, A.; Magalhães, A.C.; Kulesskiy, E.; Paveliev, M.; Rivera, C.; Rauvala, H.; Saarma, M. Heparan sulfate proteoglycan syndecan-3 is a novel receptor for GDNF, neurturin, and artemin. J. Cell Biol. 2011, 192, 153-169. [CrossRef]

29. Springer, J.; Mu, X.; Bergmann, L.; Trojanowski, J. Expression of GDNF mRNA in Rat and Human Nervous Tissue. Exp. Neurol. 1994, 127, 167-170. [CrossRef]

30. Cortés, D.; Robledo-Arratia, Y.; Hernández-Martínez, R.; Escobedo-Ávila, I.; Bargas, J.; Velasco, I. Transgenic GDNF Positively Influences Proliferation, Differentiation, Maturation and Survival of Motor Neurons Produced from Mouse Embryonic Stem Cells. Front. Cell. Neurosci. 2016, 10, 217. [CrossRef]

31. Hellmich, H.L.; Kos, L.; Cho, E.S.; Mahon, K.A.; Zimmer, A. Embryonic expression of glial cell-line derived neurotrophic factor (GDNF) suggests multiple developmental roles in neural differentiation and epithelial-mesenchymal interactions. Mech. Dev. 1996, 54, 95-105. [CrossRef]

32. Huang, L.; Guo, H.; Hellard, D.; Katz, D. Glial cell line-derived neurotrophic factor (GDNF) is required for differentiation of pontine noradrenergic neurons and patterning of central respiratory output. Neuroscience 2005, 130, 95-105. [CrossRef] [PubMed]

33. Oo, T.F.; Ries, V.; Cho, J.; Kholodilov, N.; Burke, R.E. Anatomical basis of glial cell line-derived neurotrophic factor expression in the striatum and related basal ganglia during postnatal development of the rat. J. Comp. Neurol. 2005, 484, 57-67. [CrossRef] [PubMed]

34. Buss, R.R.; Gould, T.W.; Ma, J.; Vinsant, S.; Prevette, D.; Winseck, A.; Toops, K.A.; Hammarback, J.A.; Smith, T.L.; Oppenheim, R.W. Neuromuscular Development in the Absence of Programmed Cell Death: Phenotypic Alteration of Motoneurons and Muscle. J. Neurosci. 2006, 26, 13413-13427. [CrossRef] [PubMed]

35. Saavedra, A.; Baltazar, G.; Duarte, E.P. Driving GDNF expression: The green and the red traffic lights. Prog. Neurobiol. 2008, 86, 186-215. [CrossRef] [PubMed]

36. Sotoyama, H.; Iwakura, Y.; Oda, K.; Sasaoka, T.; Takei, N.; Kakita, A.; Enomoto, H.; Nawa, H. Striatal hypodopamine phenotypes found in transgenic mice that overexpress glial cell line-derived neurotrophic factor. Neurosci. Lett. 2017, 654, 99-106. [CrossRef]

37. Pozas, E.; Ibáñez, C.F. GDNF and GFR $\alpha 1$ Promote Differentiation and Tangential Migration of Cortical GABAergic Neurons. Neuron 2005, 45, 701-713. [CrossRef]

38. Ernsberger, U. The role of GDNF family ligand signalling in the differentiation of sympathetic and dorsal root ganglion neurons. Cell Tissue Res. 2008, 333, 353-371. [CrossRef]

39. Bär, K.J.; Saldanha, G.J.F.; Kennedy, A.J.; Facer, P.; Birch, R.; Carlstedt, T.; Anand, P. GDNF and its receptor component Ret in injured human nerves and dorsal root ganglia. Neuroreport 1998, 9, 43-47. [CrossRef]

40. Trupp, M.; Rydén, M.; Jörnvall, H.; Funakoshi, H.; Timmusk, T.; Arenas, E.; Ibáñez, C.F. Peripheral expression and biological activities of GDNF, a new neurotrophic factor for avian and mammalian peripheral neurons. J. Cell Biol. 1995, 130, 137-148. [CrossRef]

41. Suzuki, H.; Hase, A.; Miyata, Y.; Arahata, K.; Akazawa, C. Prominent expression of glial cell line-derived neurotrophic factor in human skeletal muscle. J Comp. Neurol. 1998, 402, 303-312. [CrossRef]

42. Nagano, M.; Suzuki, H. Quantitative analyses of expression of GDNF and neurotrophins during postnatal development in rat skeletal muscles. Neurosci. Res. 2003, 45, 391-399. [CrossRef]

43. Zahavi, E.E.; Ionescu, A.; Gluska, S.; Gradus, T.; Ben-Yaakov, K.; Perlson, E. A compartmentalized microfluidic neuromuscular co-culture system reveals spatial aspects of GDNF functions. J. Cell Sci. 2015, 128, 1241-1252. [CrossRef] [PubMed]

44. Santos, D.; Giudetti, G.; Micera, S.; Navarro, X.; Del Valle, J. Focal release of neurotrophic factors by biodegradable microspheres enhance motor and sensory axonal regeneration in vitro and in vivo. Brain Res. 2016, 1636, 93-106. [CrossRef] [PubMed]

45. Xing, M.; Zhuang, H.; Bu, S.; Hua, L.; Darabi, M.A.; Cao, X. Gelatin-methacrylamide gel loaded with microspheres to deliver GDNF in bilayer collagen conduit promoting sciatic nerve growth. Int. J. Nanomed. 2016, 11, 1383-1394. [CrossRef] [PubMed]

46. Höke, A.; Gordon, T.; Zochodne, D.; Sulaiman, O. A Decline in Glial Cell-Line-Derived Neurotrophic Factor Expression Is Associated with Impaired Regeneration after Long-Term Schwann Cell Denervation. Exp. Neurol. 2002, 173, 77-85. [CrossRef]

47. Walker, M.J.; Xu, X.-M. History of Glial Cell Line-Derived Neurotrophic Factor (GDNF) and Its Use for Spinal Cord Injury Repair. Brain Sci. 2018, 8, 109. [CrossRef]

48. Azevedo, M.D.; Sander, S.; Tenenbaum, L. GDNF, A Neuron-Derived Factor Upregulated in Glial Cells during Disease. J. Clin. Med. 2020, 9, 456. [CrossRef]

49. Baudet, C.; Pozas, E.; Adameyko, I.; Andersson, E.; Ericson, J.; Ernfors, P. Retrograde Signaling onto Ret during Motor Nerve Terminal Maturation. J. Neurosci. 2008, 28, 963-975. [CrossRef]

50. Oppenheim, R.W.; Houenou, L.J.; Johnson, J.E.; Lin, L.-F.H.; Li, L.; Lo, A.C.; Newsome, A.L.; Prevette, D.M.; Wang, S. Developing motor neurons rescued from programmed and axotomy-induced cell death by GDNF. Nat. Cell Biol. 1995, 373, 344-346. [CrossRef]

51. Wang, Y.; Gupta, A.; Toledo-Rodriguez, M.; Wu, C.Z.; Markram, H. Anatomical, Physiological, Molecular and Circuit Properties of Nest Basket Cells in the Developing Somatosensory Cortex. Cereb. Cortex 2002, 12, 395-410. [CrossRef]

52. Nguyen, Q.T.; Parsadanian, A.S.; Snider, W.D.; Lichtman, J.W. Hyperinnervation of Neuromuscular Junctions Caused by GDNF Overexpression in Muscle. Science 1998, 279, 1725-1729. [CrossRef]

53. Wang, C.-Y.; Yang, F.; He, X.-P.; Je, H.S.; Zhou, J.-Z.; Eckermann, K.; Kawamura, D.; Feng, L.; Shen, L.; Lu, B. Regulation of Neuromuscular Synapse Development by Glial Cell Line-derived Neurotrophic Factor and Neurturin. J. Biol. Chem. 2002, 277, 10614-10625. [CrossRef] [PubMed] 
54. Stanga, S.; Zanou, N.; Audouard, E.; Tasiaux, B.; Contino, S.; Vandermeulen, G.; René, F.; Loeffler, J.; Clotman, F.; Gailly, P.; et al. APP-dependent glial cell line-derived neurotrophic factor gene expression drives neuromuscular junction formation. FASEB J. 2015, 30, 1696-1711. [CrossRef] [PubMed]

55. Keller-Peck, C.R.; Feng, G.; Sanes, J.R.; Yan, Q.; Lichtman, J.W.; Snider, W.D. Glial Cell Line-Derived Neurotrophic Factor Administration in Postnatal Life Results in Motor Unit Enlargement and Continuous Synaptic Remodeling at the Neuromuscular Junction. J. Neurosci. 2001, 21, 6136-6146. [CrossRef] [PubMed]

56. Zwick, M.; Teng, L.; Mu, X.; Springer, J.E.; Davis, B.M. Overexpression of GDNF Induces and Maintains Hyperinnervation of Muscle Fibers and Multiple End-Plate Formation. Exp. Neurol. 2001, 171, 342-350. [CrossRef]

57. Wehrwein, E.A.; Roskelley, E.M.; Spitsbergen, J.M. GDNF is regulated in an activity-dependent manner in rat skeletal muscle. Muscle Nerve 2002, 26, 206-211. [CrossRef] [PubMed]

58. McCullough, M.B.; Domire, Z.J.; Reed, A.M.; Amin, S.; Ytterberg, S.R.; Chen, Q.; An, K.-N. Evaluation of muscles affected by myositis using magnetic resonance elastography. Muscle Nerve 2011, 43, 585-590. [CrossRef]

59. Gyorkos, A.M.; Spitsbergen, J.M. GDNF content and NMJ morphology are altered in recruited muscles following high-speed and resistance wheel training. Physiol. Rep. 2014, 2, e00235. [CrossRef]

60. Stanga, S.; Caretto, A.; Boido, M.; Vercelli, A. Mitochondrial Dysfunctions: A Red Thread across Neurodegenerative Diseases. Int. J. Mol. Sci. 2020, 21, 3719. [CrossRef]

61. Qing, J.; Liu, X.; Wu, Q.; Zhou, M.; Zhang, Y.; Mazhar, M.; Huang, X.; Wang, L.; He, F. Hippo/YAP Pathway Plays a Critical Role in Effect of GDNF Against A $\beta$-Induced Inflammation in Microglial Cells. DNA Cell Biol. 2020, 39, 1064-1071. [CrossRef]

62. Pöyhönen, S.; Er, S.; Domanskyi, A.; Airavaara, M. Effects of Neurotrophic Factors in Glial Cells in the Central Nervous System: Expression and Properties in Neurodegeneration and Injury. Front. Physiol. 2019, 10, 486. [CrossRef]

63. Choi, H.Y.; Liu, Y.; Tennert, C.; Sugiura, Y.; Karakatsani, A.; Kröger, S.; Johnson, E.B.; Hammer, R.E.; Lin, W.; Herz, J. APP interacts with LRP4 and agrin to coordinate the development of the neuromuscular junction in mice. eLife 2013, 2, e00220. [CrossRef]

64. Lin, M.; Xiong, W.-C.; Mei, L. Neuromuscular Junction Formation, Aging, and Disorders. Annu. Rev. Physiol. 2018, 80, 159-188. [CrossRef]

65. De Strooper, B.; Saftig, P.; Craessaerts, K.; Vanderstichele, H.; Guhde, G.; Annaert, W.; Von Figura, K.; Van Leuven, F. Deficiency of presenilin-1 inhibits the normal cleavage of amyloid precursor protein. Nat. Cell Biol. 1998, 391, 387-390. [CrossRef] [PubMed]

66. Hage, S.; Marinangeli, C.; Stanga, S.; Octave, J.-N.; Quetin-Leclercq, J.; Kienlen-Campard, P. Gamma-Secretase Inhibitor Activity of a Pterocarpus erinaceus Extract. Neurodegener. Dis. 2014, 14, 39-51. [CrossRef] [PubMed]

67. Hage, S.; Stanga, S.; Marinangeli, C.; Octave, J.-N.; Dewachter, I.; Quetin-Leclercq, J.; Kienlen-Campard, P. Characterization of Pterocarpus erinaceus kino extract and its gamma-secretase inhibitory properties. J. Ethnopharmacol. 2015, 163, 192-202. [CrossRef] [PubMed]

68. Stanga, S.; Vrancx, C.; Tasiaux, B.; Marinangeli, C.; Karlström, H.; Kienlen-Campard, P. Specificity of presenilin-1- and presenilin2-dependent $\gamma$-secretases towards substrate processing. J. Cell. Mol. Med. 2017, 22, 823-833. [CrossRef]

69. Contino, S.; Porporato, P.E.; Bird, M.; Marinangeli, C.; Opsomer, R.; Sonveaux, P.; Bontemps, F.; Dewachter, I.; Octave, J.-N.; Bertrand, L.; et al. Presenilin 2-Dependent Maintenance of Mitochondrial Oxidative Capacity and Morphology. Front. Physiol. 2017, 8, 796. [CrossRef]

70. Hardiman, O.; Berg, L.H.V.D.; Kiernan, M.C. Clinical diagnosis and management of amyotrophic lateral sclerosis. Nat. Rev. Neurol. 2011, 7, 639-649. [CrossRef]

71. Kolb, S.J.; Kissel, J.T. Spinal Muscular Atrophy. Neurol. Clin. 2015, 33, 831-846. [CrossRef]

72. Suzuki, M.; McHugh, J.; Tork, C.; Shelley, B.; Hayes, A.; Bellantuono, I.; Aebischer, P.; Svendsen, C.N. Direct Muscle Delivery of GDNF With Human Mesenchymal Stem Cells Improves Motor Neuron Survival and Function in a Rat Model of Familial ALS Mol. Ther. 2008, 16, 2002-2010. [CrossRef] [PubMed]

73. Mohajeri, M.H.; Figlewicz, D.A.; Bohn, M.C. Intramuscular Grafts of Myoblasts Genetically Modified to Secrete Glial Cell Line-Derived Neurotrophic Factor Prevent Motoneuron Loss and Disease Progression in a Mouse Model of Familial Amyotrophic Lateral Sclerosis. Hum. Gene Ther. 1999, 10, 1853-1866. [CrossRef] [PubMed]

74. Thomsen, G.M.; Alkaslasi, M.; Vit, J.-P.; Lawless, G.; Godoy, M.; Gowing, G.; Shelest, O.; Svendsen, C.N. Systemic injection of AAV9-GDNF provides modest functional improvements in the SOD1G93A ALS rat but has adverse side effects. Gene Ther. 2017, 24, 245-252. [CrossRef] [PubMed]

75. Koistinen, H.; Prinjha, R.; Soden, P.; Harper, A.; Banner, S.J.; Dingwall, C.; Pradat, P.-F.; Loeffler, J.-P. Elevated levels of amyloid precursor protein in muscle of patients with amyotrophic lateral sclerosis and a mouse model of the disease. Muscle Nerve 2006, 34, 444-450. [CrossRef] [PubMed]

76. Bryson, J.B.; Hobbs, C.; Parsons, M.J.; Bosch, K.D.; Pandraud, A.; Walsh, F.S.; Doherty, P.; Greensmith, L. Amyloid precursor protein (APP) contributes to pathology in the SOD1G93A mouse model of amyotrophic lateral sclerosis. Hum. Mol. Genet. 2012, 21, 3871-3882. [CrossRef]

77. Stanga, S.; Brambilla, L.; Tasiaux, B.; Dang, A.H.; Ivanoiu, A.; Octave, J.-N.; Rossi, D.; Van Pesch, V.; Kienlen-Campard, P. A Role for GDNF and Soluble APP as Biomarkers of Amyotrophic Lateral Sclerosis Pathophysiology. Front. Neurol. 2018, 9, 384. [CrossRef]

78. Menduti, G.; Rasà, D.M.; Stanga, S.; Boido, M. Drug Screening and Drug Repositioning as Promising Therapeutic Approaches for Spinal Muscular Atrophy Treatment. Front. Pharmacol. 2020, 11, 592234. [CrossRef] 
79. Boido, M.; Vercelli, A. Neuromuscular Junctions as Key Contributors and Therapeutic Targets in Spinal Muscular Atrophy. Front. Neuroanat. 2016, 10, 6. [CrossRef]

80. Miller, N.; Shi, H.; Zelikovich, A.S.; Ma, Y.-C. Motor neuron mitochondrial dysfunction in spinal muscular atrophy. Hum. Mol. Genet. 2016, 25, 3395-3406. [CrossRef]

81. Cifuentes-Diaz, C.; Nicole, S.; Velasco, M.E.; Borra-Cebrian, C.; Panozzo, C.; Frugier, T.; Millet, G.; Roblot, N.; Joshi, V.; Melki, J. Neurofilament accumulation at the motor endplate and lack of axonal sprouting in a spinal muscular atrophy mouse model. Hum. Mol. Genet. 2002, 11, 1439-1447. [CrossRef]

82. Kariya, S.; Park, G.-H.; Maeno-Hikichi, Y.; Leykekhman, O.; Lutz, C.; Arkovitz, M.S.; Landmesser, L.T.; Monani, U.R. Reduced SMN protein impairs maturation of the neuromuscular junctions in mouse models of spinal muscular atrophy. Hum. Mol. Genet. 2008, 17, 2552-2569. [CrossRef] [PubMed]

83. Valsecchi, V.; Boido, M.; De Amicis, E.; Piras, A.; Vercelli, A. Expression of Muscle-Specific MiRNA 206 in the Progression of Disease in a Murine SMA Model. PLoS ONE 2015, 10, e0128560. [CrossRef] [PubMed]

84. McGovern, V.L.; Gavrilina, T.O.; Beattie, C.E.; Burghes, A.H. Embryonic motor axon development in the severe SMA mouse Hum. Mol. Genet. 2008, 17, 2900-2909. [CrossRef]

85. Murray, L.M.; Comley, L.H.; Thomson, D.; Parkinson, N.; Talbot, K.; Gillingwater, T.H. Selective vulnerability of motor neurons and dissociation of pre- and post-synaptic pathology at the neuromuscular junction in mouse models of spinal muscular atrophy. Hum. Mol. Genet. 2007, 17, 949-962. [CrossRef] [PubMed]

86. Torres-Benito, L.; Ruiz, R.; Tabares, L. Synaptic defects in spinal muscular atrophy animal models. Dev. Neurobiol. 2012, 72, 126-133. [CrossRef]

87. McGivern, J.V.; Patitucci, T.N.; Nord, J.A.; Barabas, M.-E.A.; Stucky, C.L.; Ebert, A.D. Spinal muscular atrophy astrocytes exhibit abnormal calcium regulation and reduced growth factor production. Glia 2013, 61, 1418-1428. [CrossRef]

88. Chiaretti, A.; Leoni, C.; Barone, G.; Genovese, O.; Brahe, C.; Mariotti, P.; Conti, G. Increased Levels of Glial Cell-Derived Neurotrophic Factor in CSF of Infants With SMA. Pediatr. Neurol. 2009, 41, 195-199. [CrossRef]

89. Audouard, E.; Schakman, O.; René, F.; Huettl, R.-E.; Huber, A.B.; Loeffler, J.-P.; Gailly, P.; Clotman, F. The Onecut Transcription Factor HNF-6 Regulates in Motor Neurons the Formation of the Neuromuscular Junctions. PLoS ONE 2012, 7, e50509. [CrossRef]

90. Patrón, L.A.; August, P.R. Modeling neuromuscular junctions in vitro: A review of the current progress employing human induced pluripotent stem cells. AIMS Cell Tissue Eng. 2017, 2, 91-118. [CrossRef]

91. Bakooshli, M.A.; Lippmann, E.S.; Mulcahy, B.; Iyer, N.; Nguyen, C.T.; Tung, K.; Stewart, B.A.; van den Dorpel, H.; Fuehrmann, T.; Shoichet, M.; et al. A 3D culture model of innervated human skeletal muscle enables studies of the adult neuromuscular junction. eLife 2019, 8, e44530. [CrossRef]

92. Osaki, T.; Uzel, S.G.M.; Kamm, R. On-chip 3D neuromuscular model for drug screening and precision medicine in neuromuscular disease. Nat. Protoc. 2020, 15, 421-449. [CrossRef] [PubMed]

93. Lanni, C.; Racchi, M.; Stanga, S.; Mazzini, G.; Ranzenigo, A.; Polotti, R.; Memo, M.; Govoni, S.; Uberti, D. Unfolded p53 in Blood as a Predictive Signature Signature of the Transition from Mild Cognitive Impairment to Alzheimer's Disease. J. Alzheimer's Dis. 2010, 20, 97-104. [CrossRef] [PubMed]

94. Stanga, S.; Lanni, C.; Govoni, S.; Uberti, D.; D’Orazi, G.; Racchi, M. Unfolded p53 in the pathogenesis of Alzheimer's disease: Is HIPK2 the link? Aging 2010, 2, 545-554. [CrossRef] [PubMed]

95. Stanga, S.; Lanni, C.; Sinforiani, E.; Mazzini, G.; Racchi, M. Searching for Predictive Blood Biomarkers: Misfolded p53 In Mild Cognitive Impairment. Curr. Alzheimer Res. 2012, 9, 1191-1197. [CrossRef]

96. Summers, M.J.; Rainero, I.; Vercelli, A.E.; Aumayr, G.; De Rosario, H.; Mönter, M.; Kawashima, R.; Caglio, M.; Carbone, C.; Rubino, E.; et al. The My Active and Healthy Aging (My-AHA) ICT platform to detect and prevent frailty in older adults: Randomized control trial design and protocol. Alzheimer's Dementia: Transl. Res. Clin. Interv. 2018, 4, 252-262. [CrossRef] 